\title{
Characterization of Farmer and Forage Supply in a Sheep Smallholder System in West Java, Indonesia
}

\author{
Nur Rochmah Kumalasari*, Anifah Srifani, Muhammad Agus Setiana
}

Department of Nutrition and Feed Technology, Faculty of Animal Science, IPB University, Bogor, Indonesia *Corresponding Author: nurku@apps.ipb.ac.id.

\begin{tabular}{cccc} 
Article history & & & \\
\hline Received & Received in revised form & Accepted & Available online \\
15 July 2021 & 23 August 2021 & 28 December 2021 & 31 December 2021 \\
\hline
\end{tabular}

\begin{abstract}
Forage plays a crucial role in the ruminant farm as the main diet whereas the forage availability is fluctuated, and low quality. This research was carried out to study the characteristics of sheep farming, forage diversity and supply at fattening period of local sheep in a small-scale farm area i.e., Ciaruteun Udik Village, Subdistrict Cibungbulang, Bogor Regency, at West Java, Indonesia. The study involved 64 farmers that have 5-15 sheep. Forage diversity and quality were analysed descriptive while relationship between collecting method and forage supply was performed linear model. The results showed that forage supply related to the forage collecting method, sheep ownership, forage container, and feeding time. The research was identified 69 forage species in the field around the farming area, while in the sheep barn there were 70 forage species. The differences occurred due to farmer also add forage from other sources such as paddy field, home garden and forage trader. The plants on forage sources classified as grasses were $36.3 \%, 1.50 \%$ legumes and $62.2 \%$ broadleaves plants. The highest forage diversity was found in fallow land areas around community residents. The proximate analyses showed that nutrient content on farms were similar to forage sources.
\end{abstract}

Keywords: barn, forage supply, local sheep, performance, plant diversity

\section{Introduction}

Sheep is one of the most common animals in small scale farming systems in Indonesia. Sheep population reached 17398000 head in 2018 and almost $65 \%$ at West Java [1]. High animal population indicated there were high feed requirements to fulfil animal requirements [2]. Forage plays a crucial role in the ruminant farm as the main diet that is the driving force of productive performances [3]. However, animal production meets some difficulties in many areas due to varied problem of forage supply.

In West Java, almost all sheep farmers supply forage on the barn by cut and carry system. Animal body weight in the barn depend on forage supply by farmers [4]. Most farmer are rearing the sheep on the barn and collect some forage on available land which is often of low quality and in fluctuate supply [5]. Forage diversity could improve sheep feeding palate and stimulate the average daily intake [6]. It often affected animal productivity due to grazing behaviour changes [7].

Sheep farming development requires farm management improvement and government support through agricultural policy [8]. Most of farming management in Indonesia conducted by traditional knowledge that related to social behavior, animal art and culture [9]. The improvement animal condition through new technology and management approach meets some difficulties to conducted that related with farmer's character [10]. Understanding the characteristics of the farming systems is important to determine farm improvement and management in country scale. This work was carried out to study the characteristics of sheep farming, forage diversity and supply.

\section{Material and Methods}

\subsection{Study area description}

Ciaruteun Udik Village comprises of 7 counties, i.e., Cimanggu, Ciaruteun, Layungsari, Cigula, Sukakarya, Cibereum, and Gunung Leutik. This region covers an area of 205110 hectares. It lies in latitudes $-6^{\circ} 36^{\prime} 19.4214^{\prime \prime}$ and longitudes $106^{\circ} 40^{\prime}$ 24.888", with human population of 7238 (Cibungbulang District in Number 2018). Rainfall is bimodal and ranges from $2000 \mathrm{~mm}-3000 \mathrm{~mm}$ while temperature range is $15^{\circ} \mathrm{C}-31^{\circ} \mathrm{C}$. According to Statistic Office Board (2018) the Ciaruteun Udik records over 100 farmers practicing animal farming and they keep population of 1475 sheep.

\subsection{Study design and sample size determination}

The study was designed use a descriptive cross sectional. The sample size was determined using the Slovin method described by Jeffry et al. [11]. The study involved 64 small-scale farmers that selected through a multistage, stratified sampling based on list of farmers provided by the Head of Village. Each sub 
county was apportioned it share of farmers being proportionately dependent on the total farmers population. Each farmer has the fattening sheep on traditional sheep pen and serve forage from some places in the village such as village public field, paddy field and around residential areas.

\subsection{Data collection}

Data for this study was collected between February and March 2019 through structures questionnaires. The selected dairy farms were visited to get information about farmers' data, forage sources, feeding and forage management. The research was conducted through an onsite survey on the forage source location which was purposively assigned based on interviews with farmers. The samples in each of the locations were selected through $0.5 \times 0.5$ meter sample plots of quadrant system repeated four times. Parameters observed were the diversity of indigenous forage (grasses, legumes, shrubs) and indigenous forage productivity (fresh and dry matter production). The identification and production of indigenous forage in each sample plots were then descriptively analyzed to assess the diversity and productivity of indigenous forage on the sheep pen and various forage sources. Proximate analysis was conducted on composite forage samples from forage sources and farms at the Laboratory of Feedstuff Science, Department of Nutrition and Feed Technology, Faculty of Animal Science.

\subsection{Data Analysis}

Species diversity index was calculated as the number of species each year across sampling periods. Shannon-Weiner index was calculated as $\mathrm{H}^{\prime}=-\sum \mathrm{Pi} \ln$ $(\mathrm{Pi})$, where $\mathrm{Pi}$ is the proportion of individuals represented by species $\mathrm{i}$ and $\mathrm{S}$ is the number of species. Further analysis was species richness within each plot, expressed as $R_{1}=(S-1) /(\ln (N))$, where $R_{1}$ is the species richness index in the presence of the plant species and $\mathrm{N}$ is the total number of individual plants. Species evenness was calculated as $E=H^{\prime} / \ln (S)$. Data was input to Microsoft Excel 2013 (Microsoft, USA) spreadsheet then analysed by Rx64 4.0.2. The data was analysed using linear model and descriptive statistics were presented as tables.

\section{Results and Discussion}

\subsection{Description of Farms Characteristics}

Table 1 presents farms characteristics reported during the study of 2019. The research sample showed that farmer have low education and have to do other work activities supporting the households. This study showed that farmers working in sheep production in the village of Ciaruteun Udik, West Java, apply intensive farming management practices such as sheep keeping and feed services on the barn. There were $79.69 \%$ of the farmers surveyed showed they raise livestock as side job while the other main occupations are farm laborer, farming-animal, trades/vocational skills and farming-crops. The farmers have other occupation then sheep rearing due to the low education level. In Indonesia, agricultural and animal farmer is categorized as informal job [13] that have no standard of education level and most young generation choose other work that offer higher and more stable income [12]. Most of occupation on agricultural sector offer low income in unfixed time, therefore most of farmer work some side job (such as farm labourer, vegetable trader, craftman and builder) to fulfil their needed [14]. Farm labourer are people that work at paddy field or agricultural land without have land property or own their land.

In some smallholder system, livestock ownership is important as a saving that could be sell on the critical periods such as school payment, healthy cost, commemoration and soon [15]. Animal farming as a side job could affect working hours on the barn that implicated farm performance. Cyrilla et al. [16] reported that farmer working hour's elasticity represented efficiency of animal production.

Table 1. Farm Characteristics in 2019

\begin{tabular}{lcc}
\hline Aspect & $\mathrm{n}$ & Mean $( \pm \mathrm{SD})$ \\
\hline Age of farmers (years) & 64 & $48.47(9.02)$ \\
Number of sheep & 560 & $8.75(7.72)$ \\
\hline & & $\begin{array}{c}\text { Percentage } \\
(n=64)\end{array}$ \\
Education & \\
Did not attend school & 1.56 \\
Completed primary school & 87.50 \\
Completed junior high school & 10.94 \\
Animal ownership status & \\
Owner & 90.63 \\
Profit sharing & 9.37 \\
Main occupation & \\
Farm labourer & 79.69 \\
Farming-animal & 14.06 \\
Trades/vocational skills & 4.69 \\
Farming-crops & 1.56 \\
\hline
\end{tabular}

\subsection{Forage Diversity}

In the study areas, a cut and carry system is practiced supplying forage in the farm. Farmer harvest forage from three sources, i.e., village public field, paddy field and around residential areas (Table $2)$. The index of species diversity $\left(\mathrm{H}^{\prime}\right)$ and species richness (R1) in the village public field was lower than others due to its various usages, such as football, sport, art show, grazing area, and forage sources. These activities affected plant uniformity at village public fields. 
Table 2 Index of species diversity (H'), species richness $\left(R_{1}\right)$ and species evenness $(E)$

\begin{tabular}{lccc}
\hline Forage sources & $\mathrm{H}^{\prime}$ & $\mathrm{R}_{1}$ & $\mathrm{E}$ \\
\hline Village public field & 2.87 & 4.72 & 0.81 \\
Paddy field & 3.05 & 6.00 & 0.81 \\
Around resident areas & 3.14 & 5.72 & 0.85 \\
\hline
\end{tabular}

The research identified 69 forage species from all forage sources and 70 species on farm (Table 3 ). The plants on forage sources classified as grasses were $36.3 \%, 1.50 \%$ legumes and $62.2 \%$ broadleaves plants. These results indicated the high diversity of plant and forage at Ciaruteun Udik Village. The species composition of plants was similar in forage sources and farm, however, farmers also selected forage from the sources and added other forage to feed sheep on the farm. Other forage could be added from bought forage or collected it from their garden. The selection resulted in different composition of forage on farms.

Forage for sheep classified as grasses were $35.1 \%, 4.30 \%$ legumes and $60.6 \%$ broadleaves plants. The qualified forage indicated by forage nutrient content such as crude protein, crude fibre, crude fat and ash (Table 4). Accordingly, the total nutrient content of composite as fed on each location was analysed at $10.3-12.9 \%, 21.6-22.6 \%, 1.93-2.04 \%$ and $11.8-14.3 \%$, respectively. The resulting nutrient content at forage sources and on farm were similar.

Table 4 Nutrient content at forage sources and on farm (as fed)

\begin{tabular}{|c|c|c|c|c|c|}
\hline \multirow{2}{*}{$\begin{array}{l}\text { Composite } \\
\text { Forage sample }\end{array}$} & $\begin{array}{c}\text { Dry } \\
\text { mater }\end{array}$ & Ash & $\begin{array}{c}\text { Crude } \\
\text { Fat }\end{array}$ & $\begin{array}{l}\text { Crude } \\
\text { Protein }\end{array}$ & $\begin{array}{l}\text { Crude } \\
\text { Fiber }\end{array}$ \\
\hline & \multicolumn{5}{|c|}{-------------------\%------------------ } \\
\hline & 23.7 & & 1.93 & 10.3 & 22. \\
\hline on Farm & 21.2 & 11.8 & 2.04 & 12.9 & 21.6 \\
\hline
\end{tabular}

The differences in plant species diversity, richness and evenness indexes between forage sources related to the effects of local environmental complexity [17]. The species composition of plants was similar in forage sources and farm, however, farmers also selected forage from the sources and added other forage to feed sheep on the farm. The selection resulted in different composition of forage on farms. Forage for sheep classified as grasses were $35.1 \%, 4.30 \%$ legumes and $60.6 \%$ broadleaves plants. Forage composition preference related to the higher supply and feeding value of legume and herb forage species than grasses [18].

High forage diversity on sources provides more choices for plants as sheep feed on farms. Forage selection resulted in higher nutrient composition on the farm than all forage sources (Table 3). Forage on farms has higher crude protein content (12.9\%) than forage sources $(10.3 \%)$ because there were some changes on forage fed composition. For example, the addition of Manihot esculenta and Ipomea batatas leaves could increase feed nutrient composition, due to its high protein content. Wobeto et al. [19] reported that crude protein content on Manihot esculenta leaves reach 23.3 - 35.9\% while Ipomea batatas reach $14.9 \%$ [20] until 24.9\% [21]. Sheep has a preference and an instinct to choose forage with better taste or nutritional value that is expressed as palatability value [22].

\subsection{Forage management}

The results from the study showed that the overall mean forage supply per sheep per day was 4.38 $\mathrm{kg}$ (range $=3.62-6.47 \mathrm{~kg} / \mathrm{sheep} /$ day $)$. This was significantly related to the forage collecting method, sheep ownership, forage container, and feeding time, respectively (Table 5). There were three types of forage containers to collect forage from field, i.e. carangka, karung and sundung that has different capacity (Fig. 1). Carangka and sundung are baskets that made from bamboo while karung is plastic web. The average daily forage supply per goat was greater $(\mathrm{p}=0.0000004)$ for farmer whose bought forage through trader $(4.8 \mathrm{~kg} / \mathrm{sheep} /$ day $)$, when compared to the rest $(4.34 \mathrm{~kg} / \mathrm{sheep} /$ day). Further, the ownership affected on farmer behavior on forage supply. The goat owners supply $4.83 \mathrm{~kg} / \mathrm{sheep} /$ day that were higher than profit sharing goat. 
Table 3 Identification of Plant on Forage Sources and Farm

\begin{tabular}{|c|c|c|c|c|c|}
\hline Species & $\begin{array}{c}\text { on Forage } \\
\text { sources }\end{array}$ & on Farm & Species & $\begin{array}{l}\text { Forage } \\
\text { sources }\end{array}$ & on Farm \\
\hline Achyranthes aspera & + & $\mathrm{nf}$ & Justicia procumbens & + & + \\
\hline Acmella paniculata & + & + & Kyllinga brevifolia Rottb & +++++ & + \\
\hline Ageratum conyzoides & +++++++++ & +++ & Kyllinga monochepala & + & + \\
\hline Agrostis stolonifera L. & + & + & Lamium album & + & + \\
\hline Aira caryophyllea $\mathrm{L}$. & $\mathrm{nf}$ & + & Laportea interrupta & + & $\mathrm{nf}$ \\
\hline Alternanthera brasiliana & + & + & Leersia hexandra & + & $\mathrm{nf}$ \\
\hline Alternanthera philoxeroides & + & + & Legume (unidentified) & + & $\mathrm{nf}$ \\
\hline Alternanthera sessilis & + & + & Leucaena leucocephala & $\mathrm{nf}$ & + \\
\hline Artocarpus heterophyllus & $\mathrm{nf}$ & + & Lophaterum gracile & + & + \\
\hline Asistasia gangetica & + & + & Ludwigia octovalvis & + & + \\
\hline Axonopus compressus & +++ & ++ & Manihot esculenta & $\mathrm{nf}$ & + \\
\hline Biden pilosa & + & + & Melastoma affine & + & $\mathrm{nf}$ \\
\hline Boehmeria nivea & + & + & Micania micrantha & +++++++++ & ++++ \\
\hline Boehmeria cf. Japonica & + & $\mathrm{nf}$ & Mimosa pudica & + & + \\
\hline Borreria laewis & + & $\mathrm{nf}$ & Nephrolephis biserrata & + & + \\
\hline Brachiaria decumbens & + & + & Origanum sp & ++ & + \\
\hline Brachiaria humidicola & + & + & Ottochloa nodosa & $\mathrm{nf}$ & + \\
\hline Brachiaria mutica & + & + & Oxalis barrelieri & + & $\mathrm{nf}$ \\
\hline Brachiaria ruziziensis & + & + & Panicum repens & +++++++++ & +++ \\
\hline Calopogonium mucunoides & $\mathrm{nf}$ & + & Panicum sp & + & $\mathrm{nf}$ \\
\hline Chromolaena odorata & $\mathrm{nf}$ & + & Paperomia pellucida & + & + \\
\hline Cleome rutidosperma & + & + & Parietaria judaica & $\mathrm{nf}$ & + \\
\hline Commelina benghalensis & $\mathrm{nf}$ & + & Paspalum commersoni & + & + \\
\hline Commelina diffusa & +++++++++ & +++++ & Paspalum conjugatum & +++++++ & +++ \\
\hline Cyanthilium cinereum & + & + & Paspalum dilatatum & + & + \\
\hline Cyathula prostata & + & + & Pennisetum purpureum & + & + \\
\hline Cyclosorus aridus & $\mathrm{nf}$ & + & Phyllanthus urinaria & + & + \\
\hline Cyclosorus sp & + & + & $\begin{array}{l}\text { Pleetranthus cf. } \\
\text { Monostachyus }\end{array}$ & + & + \\
\hline Cynodon dactylon & + & + & Pleocnemia irregularis & $\mathrm{nf}$ & + \\
\hline Cyperus helferi & + & + & Portulaca oleracea & + & + \\
\hline Cyperus rotundus & + & + & Prunella vulgaris & + & + \\
\hline Cyrtococcum oxyphylum & ++++++ & +++ & Pteridium aqullinum & $\mathrm{nf}$ & + \\
\hline Digitaria ciliaris & + & + & Ruellia repens & + & $\mathrm{nf}$ \\
\hline Digitaria radicosa & + & + & Setaria barbata & + & + \\
\hline Digitaria sanguinalis & + & + & Sida rhombifolia & + & + \\
\hline Digitaria setigera & $\mathrm{nf}$ & + & Solanum nigrum & + & + \\
\hline Echinochloa colona & $\mathrm{nf}$ & + & Spaghneticola trilobata & + & + \\
\hline Eclipta alba & + & + & Spermacoce alata & & + \\
\hline Eclipta prostata & + & $\mathrm{nf}$ & Spermacoce exilis & + & + \\
\hline Eleusine indica & + & + & Sphagneticola trilobata & ++++++ & +++ \\
\hline Emilia sonchifolia & + & $\mathrm{nf}$ & Strobilanthes crispus & + & $\mathrm{nf}$ \\
\hline Euphorbia heterophylla & $\mathrm{nf}$ & + & $\begin{array}{l}\text { Struchium } \\
\text { sparganophorum }\end{array}$ & + & + \\
\hline Euphorbia hirta & $\mathrm{nf}$ & + & Synedrella nodiflora & $\mathrm{nf}$ & + \\
\hline Galinsoga parviflora & + & + & Talinum fruticosum & + & + \\
\hline Ipomoea batatas & $\mathrm{nf}$ & + & & & \\
\hline
\end{tabular}

Forage sources $=$ village public field, paddy field and around residential areas; $+=$ found in small amount; $>+=$ found in larger amount; $\mathrm{nf}=$ not found 
Forage management on smallholder's system consist of two parts, i.e.: forage supply and feeding management. There were several variables affect forage supply in the barn, i.e. number of sheep, forage collecting method, animal ownership, container and animal feeding frequency.

Table 5 Relationship between variables and forage supply in the barn

\begin{tabular}{|c|c|c|c|}
\hline Variable & $\mathrm{n}$ & $\begin{array}{c}\text { Mean of } \\
\text { forage supply } \\
\text { for each sheep } \\
\text { (as fed) }\end{array}$ & P-value \\
\hline Number of sheep & 64 & 4.38 & 0.0019 \\
\hline \multicolumn{4}{|l|}{$\begin{array}{l}\text { Collecting } \\
\text { method }\end{array}$} \\
\hline By the farmer & 62 & 4.34 & \multirow[b]{2}{*}{0.0000004} \\
\hline $\begin{array}{l}\text { By forage } \\
\text { labour }\end{array}$ & 2 & 4.80 & \\
\hline \multicolumn{4}{|l|}{ Forage container } \\
\hline Carangka & 7 & 4.50 & \multirow{3}{*}{0.0959} \\
\hline Karung & 46 & 4.07 & \\
\hline Sundung & 11 & 5.83 & \\
\hline \multicolumn{4}{|l|}{$\begin{array}{l}\text { Animal } \\
\text { ownership }\end{array}$} \\
\hline Owner & 58 & 4.83 & \multirow{2}{*}{0.0464} \\
\hline Profit sharing & 6 & 3.61 & \\
\hline \multicolumn{4}{|l|}{ Feeding time } \\
\hline 2 times & 26 & 4.27 & \multirow{3}{*}{0.00007} \\
\hline 3 times & 38 & 5.46 & \\
\hline 4 times & 8 & 6.47 & \\
\hline
\end{tabular}

Farmer could supply more forage through forage trading than collect by themselves because most of them have other occupation (Table 1). In this research, animal owner has more concern to supply forage in the barn than profit sharing. Putranto [8] reported that animal management on profit sharing depends on several factors, including farmers' knowledge and age. Old farmers $(>45$ years old) have plenty traditional knowledge in animal raising although they have problem to collect forage due to time and energy sharing with their main occupation. It also would be affected their management in forage distribution in the barn.
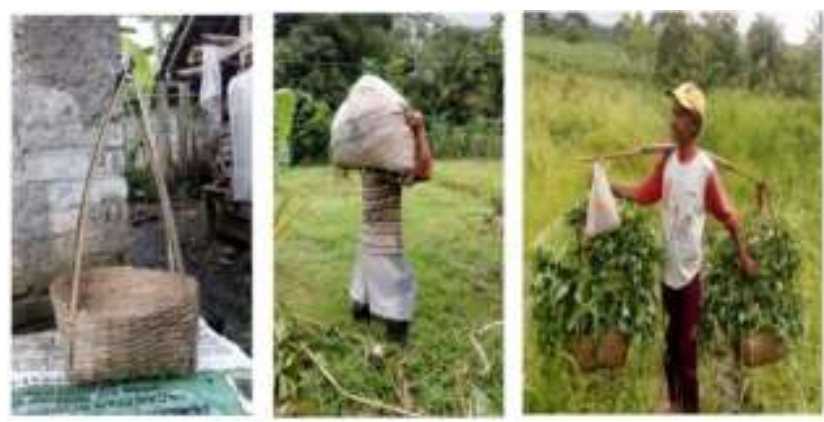

Figure 1. Forage container: carangka, karung and sundung (from left)

In the village, forage supply depends on collecting method that carried out by farmer or through forage trader. Forage collecting by the farmer related with number of their sheep, farmer age and main occupation. Only two farmer bought forage from trader because they could not manage to collect enough forage for their sheep (more than 40 head).

One farmer age already 60 years old therefore he needs to buy forage from trader, although his main occupation as sheep farmer. Some farmers adapt their work on animal prefer to feeding their animal twice (in the morning and afternoon).

\section{Conclusion}

The characteristics of sheep farming in the village is built by several factors such as farmer education and occupation, animal ownership, forage diversity and supply system. Farmer apply stall farming management practices such as sheep keeping and feed services on the barn. The main feed is forage that supply related to the forage collecting method, sheep ownership, forage container, and feeding time.

\section{References}

[1]. Direktorat Jendral Peternakan dan Kesehatan Hewan, "Statistik Peternakan dan Kesehatan Hewan", 2018. Jakarta (ID): Direktorat Jendral Peternakan dan Kesehatan Hewan Kementrian Pertanian RI

[2]. W. Asmanah, and Sukaesih, "Keragaman jenis pakan ternak dan ketersediaannya di wilayah sekitar Taman Nasional Gunung Halimun Salak". in Prosiding Seminar Nasional Masyarakat Biodiversitas Indonesia, 1 October 2015; Bogor, Indonesia: Masyarakat Biodiversitas Indonesia, pp.1565-1569

[3]. R.J. Wilkins, "Forages and Their Role in Animal Systems" In: D.I. Givens, E. Owen, R.F.E. Axford, H.M. Omed, editors. Forage Evaluation in Ruminant Nutrition. 2000. Oxon, Oxfordshire, EN: CABI Publishing, 493 p.

[4]. S. Smaali, "Correlation between weight and BCS of Ouled Djellal ewes in an accelerated lambing farm. Livest. Res. Rural. Dev. vol. 31, no. 4, pp. 46. 2019

[5]. H.M.J. Udo, and I.G.S. Budisatria "Fat-tailed sheep in Indonesia; an essential resource for smallholders", Trop. Anim. Health. Prod. vol. 43, no. 7, pp. 1411-8 2011. doi: 10.1007/s11250-0119872-7

[6]. C. Feng, S. Ding, T. Zhang, Z. Li, D. Wang, L. Wang, C. Liu, J. Sun, and F. Peng, "High plant diversity stimulates foraging motivation in grazing herbivores", Basic Appl. Ecol. pp. 1-9. 2015. doi: 10.1016/j.baae.2015.09.004.

[7]. M.A. Sanderson, S.C. Goslee, K.J. Soder, R.H. 
Skinner, B.F. Tracy, and A. Deak, "Plant species diversity, ecosystem function, and pasture management-A perspective", Canadian J. Plant Sci. vol. 87, no. 3, pp. 479-487. 2007. doi: 10.4141/P06-135

[8]. R. Putranto, "Analisis keuntungan peternak sistem gaduhan di Desa Pogalan Kecamatan Pakis Kabupaten Magelang”, Econ. Soc. Develop. Stud. vol. 3, no. 2, pp. 1-31. 2016

[9]. R. Hidayatuloh, W. Darmawan, and S. Dwiatmini, "Seni laga ketangkasan domba garut dalam perspektif structural fungsional di Desa Cikandang Kecamatan Cikajang Kabupaten Garut", J. Budaya Etnika. vol. 3, no. 2, pp. 115150. 2019

[10].P. Fatch, C. Masanganoa, J.F.M. Kamoto, I. Jordan, T. Hilger, I. Mambo, A. Kalimbira, and E. Nuppenau, "Are farmer perceptions among significant determinants of adoption of agricultural diversity in Malawi? A case of Lilongwe District", J. Agric. Rural Dev. Trop. Subtrop., vol. 121, no. 2., pp. 277-288. 2020. doi: 10.17170/kobra-202011262276

[11].J. Jeffry, Tejada, and J. Punzalan, "On the misuse of Slovin's formula", Philipp. Stat. vol. 1, no. 61, pp. $129-136.2012$

[12].N. Malikah, "Pragmatisasi pendidikan dalam dunia kerja", J. Pend. Islam. vol. 8, no. 1, pp. 155170. 2014

[13].F. Junaidi, "Pengaruh pendidikan, upah dan kesempatan kerja terhadap pengangguran terdidik di Provinsi Jambi", e-Jurnal Ekon. Sumberdaya \& Ling. vol. 5, no. 1, pp. 26-32. 2016.

[14].C.A.B.E. Lubis, "Pengaruh jumlah tenaga kerja, tingkat pendidikan pekerja dan pengeluaran pendidikan terhadap pertumbuhan ekonomi" $J$. Economia. vol. 10, no. 2, pp. 187-193. 2016.

[15].F.D. Perwitasari, Bastoni, and B. Arisandi, "Kajian aspek sosial dan ekonomi usaha ternak domba secara intensif di KTT Haur Kuning
Desa Ciawigadjah" J. Ilmu Ternak. vol. 19, no. 1, pp. 1-9. 2019. doi: 10.24198/jit.v19i1.18648

[16].L. Cyrilla, Z. Moesa, and S.M.P. Putri, "Efisiensi produksi usaha peternakan domba di Desa Cibunian Kecamatan Pamijahan Kabupaten Bogor", Med. Pet. vol. 33, no. 1, pp. 55-60. 2010.

[17].N.R. Kumalasari, and E. Bergmeier, "Effects of surrounding crop and semi-natural vegetation on the plant diversity of paddy fields", Agric. Food Secur. vol. 3, no. 15, 2014. doi: 10.1186/20487010-3-15

[18].P.D. Kemp, P.R. Kenyon, and S.T. Morris "The use of legume and herb forage species to create high performance pastures for sheep and cattle grazing systems", Rev. Bras. Zootec. vol. 39, pp. 169-174. 2010. doi: 10.1590/S151635982010001300019

[19].C. Wobeto, A.D. Correa, C.M.P. de Abreu, C.D. dos Santos, and J.R. de Abreu, "Nutrients in the cassava (Manihot esculenta Crantz) leaf meal at three ages of the plant", Ciencia e Tecnologia de Alimentos Campinas. vol. 26, no. 4, pp. 865-86. 2006.

[20].O.T. Osuntokun, M.A. Yusuf-Babatunde, and O.O. Fasila, "Components and Bioactivity of Ipomoea batatas (L.) (Sweet Potato) Ethanolic Leaf Extract" Asian J. Adv. Res. \& Rep. vol. 10, pp: $\quad 10-26 . \quad 2020 . \quad$ doi: 10.9734/AJARR/2020/v10i/130232.

[21].B.S. Antia, E.J. Akpan, P.A. Okon, and I.U. Umoren, "Nutritive and anti-nutritive evaluation of sweet potatoes (Ipomea batatas) leaves", Pak. J. Nutr. vol. 5, no. 2, pp. 166-168. 2006. doi: 10.3923/pjn.2006.166.168

[22].A. Kirilov, and V. Vasileva, "Palatability of Subterranean clover and some perennial grasses and legume forage crops," JGIASS. vol. 4, no. 4, pp. $152-155.2016 .2$ doi: 10.22194/JGIASS/4.4.761 